TITLE:

\title{
Response of Alpha-fetoprotein to Chemotherapy in Patients with Hepatomas(Abstract_要旨 )
}

$\operatorname{AUTHOR}(S)$ :

Matsumoto, Yoshiro

\section{CITATION:}

Matsumoto, Yoshiro. Response of Alpha-fetoprotein to Chemotherapy in Patients with Hepatomas. 京都大学, 1975, 医学博士

ISSUE DATE:

1975-07-23

URL:

http://hdl.handle.net/2433/220768

RIGHT: 


\section{【111】}

\begin{tabular}{|c|c|}
\hline 氏 & 本 由 朗 \\
\hline 学位の種類 & 医 \\
\hline 学位記番号 & 論 医 博 第 606 号 \\
\hline 学位授与の日付 & 昭和 50 年 7 月 23 日 \\
\hline 位授与の要件 & 学 位規則第 5 条第 2 項該 当 \\
\hline 位論文題目 & $\begin{array}{l}\text { Response of Alpha-fetoprotein to Chemotherapy in Patients } \\
\text { with Hepatomas }\end{array}$ \\
\hline
\end{tabular}

（原発性肝癌の化学療法におけるアルファフェトプロテインの動態）

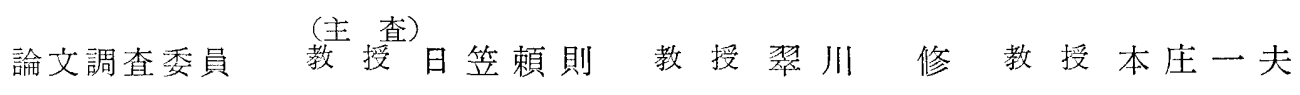

\section{論文内容の要旨}

$\alpha$-Fetoprotein (AFP) が, 原発性肝細胞癌から産生されることが Abelev, Tatarinov らによって発表 されて以来 AFP はへパトーマの診断上重要な位置を占めるに至った。ヘパトーマ患者の血中 AFP 10 $\mu \mathrm{g} / \mathrm{ml}$ 以上 (AFP 陽性) の症例では, 腫痬の増大とともに上昇し, 完全に腫瘍が切除されれば 3.5 日の 半減期で速やかに血中から消失することが知られている。著者はその turn over の速さに着目し, 化学療 法などの効果判定への利用を考光, 臨床効果と血中 AFP 值の変動の関係を検索し, から臨床検查法とし ての有効性を検討した。

抗 AFP 血清は, 純粋な AFPを馬に免疫して得た単一高純度の血清を用い, Ouchterlony の二重挔散 法礼よび Mancini の single radial immunodiffusion 法 (SRID 法)によって血中 AFPを测定した。

京大病院を訪れた約 400 名の各種疾患々者について AFP を測定した。63名のヘパトーマ患者のうち45 名 $(71.7 \%)$ AFP 陽性であった。一方63名のうち39名の切除不能肝癌に次の 3 種類の化学療法を行な ったが本論文では26名の AFP 陽性患者を対象とした。また全経過中 AFP は, 1 週 1 回測定した。化学 療法は経大腿的肝動脈内㧴管留置法(マイトマイシンC $10 \mathrm{mg} /$ 回, 毎週 1 回), 腹脭動脈内大量投与法 (20 $\mathrm{mg} /$ 回 $2 \sim 3$ 月に 1 回) 特よび経静脈性全身投与法 (FAMT 療法) で, 造血能に異常をきたさない限り投 与を続けた。臨床的効果判定基準は, 著効, 有効, 無効とした。「著効」は肝シンチ上 $50 \%$, または血管 造影上 $30 \%$ 以上の腫瘍の縮少と, S-GOT, LDH, ALP の50\%以上の改善と自覚症状の好転が 3 ケ月以上 続く場合，「有効」は自覚症状の改善と腫瘍縮少が50\%以内（肝シンチ上）にとどまり，肝機能の改善も $50 \%$ 以内の状態が 2 ケ月上上続く場合, そして「無効」は自他覚症状の改善が認められず, 腫瘍が増大す る場合である。26例の AFP 陽性肝癌の化学潦法中, 血清 AFP の推移怯次の 3 群のパターンに大別出来 た。すなわち第 1 群は AFP 值が治療前の $50 \%$ 以下に下降し, その状態が 3 ケ月以上持続する場合, 第 2 群は AFP 值は治療前值の50\%以内にとどまる。第3 群は治療にもかかからず上昇を続ける場合である。 すなわら 26 名中 9 名が第 1 群のパターンを, 同じく 9 名が第 2 群, そして 8 名が第 3 群を示した。そこで 
臨床効果と血清 AFP 変動のパターンとの関係をみると, 第 1 群の AFP パターンを示した 9 名中 6 名が 臨床効果の上で著効を示し，3名が有効で無効例は認められなかった。また第 2 群 AFP パターンを示し た他の 9 名のうち 8 名が有効， 1 名が無効であった。残る 8 名の第 3 群は全例無効であった。また第 1 群 のパターンを示した著効例では血清 AFP の下降より 2 〜 週遅れて LDH, S-GOT, ALP などが, 改善さ れることを知った。

今まで血清 AFP 值の変動から化学療法の効果を判定しょうとした報告は少ない。Lin らはOuchterlony 法によって判定しているが，それでは客観性にそしく，明確なる基準を作り得なかった。Purves はバン フー族の原発性肝癌を対象に多数の症例に種々の化学療法を行ない, SRID 法によって血清 AFP を測定 して AFP 下降例を示しているが，その効果判定のクライテリアを示すに至らなかった。著者は AFP 陽 性のヘパトーマ患者に化学療法を行ない厳密な効果判定基準と血清 AFP 值の変動パターンの関係から第 1 群 $\mathrm{AFP}$ パターンは臨床的には著効, 第 2 群 AFP パターンは有効, そして第 3 群は無効を示すことを 見出した。従って従来は肝癌に対する化学療法の効果判定は繁雑で, 客観性に乏しい方法で行なわれてい たが，上記の結果から血清 AFP の動態から最も客観的でから速やかに，その効果が判定出来ることを証 明し，原発性肝癌の治療上有力な手段の一つとなるものと思う。

\section{論文審 査の結果の要旨}

63例の原発性肝癌症例について, 血中アルファフェトプロテイン (AFP) を測定し, そのら号の化学療 法を行った症例のなかで, 血中 AFP $10 \mathrm{mg} / \mathrm{ml}$ 以上の症例を対象に, その血中濃度の推移と臨休効果の関 係に検詿を加光た。

すなわち, 化学療法を行った症例の血中 AFP の推移には 3 種類の型のあることを知った。他方, 腫瘤 の縮少, 肝機能の改善等を基準として, 臨床上の籗密な効果判定基準を作成し, 化学療法の臨床上の効果 を判定した。ついで, 各症例について AFP の 3 種の型と臨床効果を対比すると, AFP の 3 種類の型が臨 床上著効, 有効, 無効の 3 群とよく一致することを確認し, しかも AFP の变動が他の指標よりも早期に その効果を反映することを知り, 血中 AFP の測定による原発性肝細胞癌の化学療法に特ける効果判定基 準を作成した。

以上の研究は原発性肝細胞癌の治療効果判定に大きく貢献するとともに, さらに, 肝癌の新しい治療法 の開発ならびに発癌機構の解明, 肝癌の進展過程の観察等に寄与するところが多い。

よって，本論文は医学博士の学位論文として洒值あるものと認める。 